\title{
CHARACTERIZATION OF THE CHEMICAL COMPOSITION OF THE ESSENTIAL OILS FROM Annona emarginata (Schltdl.) H. Rainer 'terra-fria' AND Annona squamosa L.'
}

\author{
FELIPE GIROTTO CAMPOS ${ }^{2}$, DANIEL BARON ${ }^{3}$, MARCIA ORTIZ MAYO MARQUES ${ }^{4}$, \\ GISELA FERREIRA ${ }^{5}$, CARMEN SILVIA FERNANDES BOARO $^{5}$
}

ABSTRACT - The objective of this study was to characterize the chemical composition of the essential oil from the leaves of Annona emarginata (Schltdl.) H. Rainer 'terra-fria' and Annona squamosa L. The species were grown in a greenhouse for 18 months, which nutrient solution was applied weekly; the plants were then harvested and the leaves dried to extract the essential oil. The essential oil was analyzed by gas chromatography and mass spectrometry to study its chemical profiles. Eleven substances were found in the essential oil of $A$. emarginata, primarily $(E)$-caryophyllene $(29.29 \%),(Z)$-caryophyllene $(16.86 \%)$, $\gamma$-muurolene $(7.54 \%), \alpha$-pinene $(13.86 \%)$, and tricyclene $(10.04 \%)$. Ten substances were detected in the oil from $A$. squamosa, primarily $(E)$-caryophyllene (28.71\%), $(Z)$-caryophyllene (14.46\%), $\alpha$-humulene (4.41\%), camphene (18.10\%), $\alpha$-pinene (7.37\%), $\beta$-pinene (8.71\%), and longifolene (5.64\%). Six substances were common to both species: $(E)$-caryophyllene, $(Z)$-caryophyllene, $\alpha$-humulene, camphene, $\alpha$-pinene, and $\beta$-pinene.

Index terms: Annonaceae, secondary metabolites, terpenes, pharmacological potential.

\section{CARACTERIZAÇÃO DO PERFIL QUÍMICO DO ÓLEO ESSENCIAL DE Annona emarginata (Schltdl.) H. Rainer 'terra-fria'e Annona squamosa L.}

RESUMO-O objetivo do presente estudo foi caracterizar a composição química do óleo essencial das folhas de Annona emarginata (Schltdl.) H. Rainer 'terra-fria' e Annona squamosa L. As espécies foram cultivadas em casa de vegetação, com aplicação semanal de solução nutritiva até completar 18 meses, quando se realizaram a colheita e a secagem das folhas para a extração do óleo essencial, analisado por cromatografia gasosa acoplada à espectrometria de massas, para estudo dos perfis químicos. Onze substâncias majoritárias foram encontradas no óleo essencial de A. emarginata: $(E)$-cariofileno-29,29\%; $(Z)$-cariofileno-16,86\%; $\gamma$-muroleno-7,54\%; $\alpha$-pineno-13,86\%; tricicleno-10,04\%. No óleo de $A$. squamosa, 10 substâncias foram detectadas, entre elas: $(E)$-cariofileno-28.71\%; $(Z)$-cariofileno-14,46\%; $\alpha$-humuleno-4,41\%; canfeno-18,10\%; $\alpha$-pineno-7,37\%, e $\beta$-pineno-8,71\%; longifoleno-5,64\%; majoritárias. (E)-cariofileno; $(Z)$-cariofileno; $\alpha$-humuleno; canfeno; $\alpha$-pineno, e $\beta$-pineno foram as seis substâncias comuns às duas espécies.

Termos para indexação: Annonaceae, metabólitos secundários, terpenos, potencial farmacológico.

\footnotetext{
${ }^{1}$ (Trabalho 208-13) - Recebido em: 20-05-2013. Aceito para publicação em: 29-01-2014. V Congresso Internacional \& Encontro Brasileiro sobre Annonaceae: do gene à exportação (19 a 23 de Agosto de 2013). Botucatu-SP

${ }^{2}$ Master's student in Horticulture, Agronomy Sciences College, Universidade Estadual Paulista “Júlio de Mesquita Filho" (UNESP) Botucatu Campus, São Paulo-SP, Brazil. Caixa Postal 237. E-mail address: felipegttbio@hotmail.com

${ }^{3}$ Doctoral student in Botany, Biosciences Institute (IB), UNESP, Botucatu Campus, SP, Brazil; CP. 510. E-mail: agroozzy@yahoo.com.br ${ }^{4}$ Researcher at the P\&D Center of Vegetable Genetic Resources, Agronomy Institute, Campinas, SP, Brazil. E-mail: mortiz@iac.sp.gov.br ${ }^{5}$ Associate Professor of the Botany Department , Biosciences Institute, UNESP, Botucatu Campus, SP, Brasil; CP 510. E-mail: csfboaro@ ibb.unesp.br
} 


\section{INTRODUCTION}

Annona is an important genus of the Annonaceae family, primarily because of its edible fruits. The genus Cananga (Annonaceae) includes species with industrially important essential oils (CHATROU et al., 2012).

Recent taxonomic studies using molecular techniques have reorganized the species and genera of the Annonaceae family. Several genera have been included in other genera (SURVESWARAN et al., 2010; ZHOU et al., 2010; COUVREUR et al., 2012). These reorganizations include the proposal of Rainer (2007) that the genus Rollinia A. St.-Hil. be treated as a synonym of the genus Annona. However, the scientific literature often refers to Rollinia A. St.Hil. In the present study, Rollinia will be treated as a synonym of Annona.

Previous studies have shown that the species of the Annonaceae family exhibit a great diversity of substances produced by their secondary metabolism. These compounds include aromatic substances, phenolic acids, steroids, alkaloids, acetogenins, and essential oils (LEBOEUF et al., 1982; LIMA, 2007; REIS, 2011).

The term essential oil refers to a group of aroma-bearing substances resulting from secondary metabolism (SPERRY, 2000). These substances are often produced in secretory structures, such as glandular cells and oleiferous canals, or in other specific structures (SIMÕES; MARIOT, 2003). These chemicals include, e.g., terpenes (monoterpenes and sesquiterpenes), phenylpropanoids, compounds containing nitrogen and sulfur, and aromatic compounds (BAKKALI et al., 2008). The essential oils have cytotoxic and phytotoxic effects (BAKKALI et al., 2008), which function to protect the plants against damage caused by arthropods; in addition, they are potentially very useful in medicine (LIMA et al., 2003; POTZERNHEIM et al., 2006; REGNAULT-ROGER et al., 2012). During the development of plants, secondary metabolism may be affected by numerous environmental factors, e.g., radiation, temperature, humidity, wind, and soil characteristics (WANG et al., 2012). According to Kamatou et al. (2008), several environmental conditions throughout the year affect the production, concentration, and biological activity of essential oils by plants. In nature, essential oils in plants serve important defensive functions, including bactericidal activity against Gram-positive and Gram-negative forms, antiviral and antifungal activity, insecticidal functions, and defense against herbivores. These compounds are also important for attracting dispersers of pollen and seeds and for repelling undesirable organisms (BAKKALI et al., 2008; RIVOAL et al., 2010). Several studies have been conducted to demonstrate the potential of essential oils in the pharmaceutical industry based on the functions of these oils in plant defense (EDRIS, 2007).

A number of studies have been performed in view of the pharmacological potential of the species of the Annonaceae family (OCAMPO; OCAMPO, 2006). The essential oil of $A$. coreacea Mart. has been found to exhibit antiprotozoan activity (SIQUEIRA et al., 2011). Muganza et al. (2012) conducted ethnopharmacological reviews of 33 plant species, including three species belonging to the Annonaceae family. These three species - Anonidium mannii Engl. \& Diels, Enantia chlorantha Oliv., and Isolona hexaloba Engl. \& Diels - were found to show antiinflammatory activity affecting the blood vessels; antiprotozoan activity; and antimalarial activity and activity against headaches and appetite loss, respectively. Lima et al. (2012) have studied Annona cornifolia A. St.-Hil. and have noted that this species is a promising source of drugs for treating cancer because of its antioxidant and cytotoxic potential. Costa et al. (2009) have described the antimicrobial and antimalarial activities of $A$. foetida Mart. The biological activity cited for these three species of Annonaceae has been attributed to the effects of essential oils (COSTA et al., 2009; SIQUEIRA et al., 2011; LIMA et al., 2012).

The species A. emarginata 'terra-fria' is economically important because it is the most used rootstock in Brazil for cultivating atemoya, a plant whose fruit has great economic potential because of its organoleptic characteristics (TOKUNAGA, 2005). A. emarginata is highly resistant to stem borers, pests, and disease (KAVATI; WATANABE, 2010). The ecological resilience of the species in nature (rusticity) allows it to adapt to different nutritional conditions (BARON et al. 2013). In the Annonaceae family, essential oils occur not only in the leaves but also in other parts of the plant, such as the bark and roots, as previously shown by Boyom et al. (2011) and Muganza et al. (2012). A. squamosa (custard apple) and A. cherimola Mill. (cherimoya) are the species from which the atemoya hybrid originated. The potential biological activity of $A$. squamosa L. has been investigated. Seffrin et al. (2010) studied the seed extract of this species and found that it showed larvicidal activity against Trichoplusia ni. Other studies performed with the essential oil of the bark of A. squamosa $\mathrm{L}$. have demonstrated its activity against Gram-positive 
bacteria. The author of such study has related this activity to the high percentage of caryophyllene oxide $(29.38 \%)$ contained in the preparation. This form of biological activity has previously been described in the literature for such component (CHAVAN et al., 2006). The essential oil extracted from the leaves, bark, and stems of $A$. squamosa has been found to contain $\alpha$-pinene, limonene, $\beta$-cubebene, $\beta$-caryophyllene, spathulenol, caryophyllene oxide, and $\alpha$-cadinol as major components (THANG et al., 2012).

Although several studies on the Annonaceae family can be found in the literature, there are few reports about the chemical composition of the essential oil of the leaves of $A$. emarginata 'terrafria' and A. squamosa. These species are not only important to atemoya cultivation but may also show pharmacological activity of economic interest.

The goal of this study was to characterize the chemical composition of the essential oil extracted from leaves of $A$. emarginata 'terra-fria' and $A$. squamosa.

\section{MATERIALS AND METHODS}

This study was conducted in a greenhouse with controlled temperature and humidity, located in the experimental area of the Instituto de Biociências, Universidade Estadual Paulista, UNESP - Câmpus Botucatu, Departamento de Botânica, $48^{\circ} 24^{\prime} 35^{\prime \prime} \mathrm{W}$, $22^{\circ} 49^{\prime} 10^{\prime \prime} \mathrm{S}, 850 \mathrm{~m}$ above sea level.

Specimens of $A$. emarginata 'terra-fria' and $A$. squamosa (custard apple) were obtained by germinating seeds from São Bento do Sapucaí, $45^{\circ} 44^{\prime} 11^{\prime \prime} \mathrm{W}, 22^{\circ} 41^{\prime} 18^{\prime \prime} \mathrm{S}, 874 \mathrm{~m}$ above sea level. The seeds were sown in expanded polystyrene trays without dividers. During early development, the seedlings were transplanted to $10-\mathrm{L}$ pots filled with a mixture of red earth, medium-textured vermiculite, and coconut fiber. The young plants then received weekly applications of Yogen ${ }^{\circledR} 3$ nutrient solution containing $25 \% \mathrm{~N}, 6.5 \% \mathrm{P}, 6.7 \% \mathrm{~K}, 0.053 \% \mathrm{Zn}$, $0.02 \% \mathrm{Co}, 0.077 \% \mathrm{Mn}$, and $0.022 \% \mathrm{~B}\left(\right.$ YOORIN $\left.^{\circledR}\right)$, as well as calcium nitrate, $\mathrm{Ca}\left(\mathrm{NO}_{3}\right)_{2}(\mathrm{HOAGLAND}$; ARNON, 1950). The nutrients provided were sufficient to ensure vegetative growth until 18 months after the transplantation to the pots, when leaves were collected for oil extraction.

The leaves of $10 \mathrm{~A}$. emarginata 'terra-fria' plants and $15 \mathrm{~A}$. squamosa plants were collected to obtain sufficient dry mass for essential oil extraction. The leaves were collected in the morning from 10:00 to 12:00 and then placed in a greenhouse (drying chamber) with forced-air heaters at $40^{\circ} \mathrm{C}$ for 48 hours until a constant dry mass was obtained. After the completion of drying, $80 \mathrm{~g}$ of the dry mass of the leaves was hydrodistilled in a Clevenger-type apparatus for 2 hours to extract the essential oils. The oils were separated from the aqueous phase with the addition of solvent dichloromethane $(0.5 \mathrm{~mL}$, Merck, chromatographic grade), and the solution was stored in amber glass bottles and kept in a freezer at $-20^{\circ} \mathrm{C}$ prior to chemical analysis.

The chemical analysis of the essential oils was performed with gas chromatography coupled with electron-ionization mass spectrometry $(70 \mathrm{eV})$ (GC-MS, Shimadzu, QP-5000). An OV-5 capillary column (Ohio Valley Specialty Chemical, Inc.; 30.0 $\mathrm{m} \times 0.25 \mathrm{~mm} \times 0.25 \mu \mathrm{m}$ ) was used with the following operating characteristics: injector at $240^{\circ} \mathrm{C}$, detector at $230^{\circ} \mathrm{C}$, split injection $(1 / 20)$, injection volume: $1 \mu \mathrm{L}$ of solution, $\operatorname{ramp} 60^{\circ} \mathrm{C}$ at $240^{\circ} \mathrm{C}, 3^{\circ} \mathrm{C} / \mathrm{min}$. The substances were identified by comparing their mass spectra with the GC-MS (Nist. 62 lib.) system database based on retention indices (ADAMS, 2007). The retention indices were obtained by injecting a standard mixture of hydrocarbons $\left(\mathrm{C}_{9}-\mathrm{C}_{24}\right)$ with the same chromatography conditions described above and then applying the equation of Van Dool \& Kratz (1963).

\section{RESULTS AND DISCUSSION}

Eleven substances were identified in the essential oil of the leaves of $A$. emarginata 'terrafria', and 10 components were identified in the oil of A. squamosa, as shown in Table 1. The major substances in the oil of both species were sesquiterpenes and monoterpenes. These results agree with the findings for $A$. glabra L., A. squamosa L., A. muricata L., and $A$. reticulata L. reported by Thang et al. (2012).

The essential oil of A. emarginata 'terra-fria' included five principal constituents: $(E)$-caryophyllene (29.29\%), (Z)-caryophyllene (16.86\%), $\gamma$-muurolene (7.54\%), $\alpha$-pinene $(13.86 \%)$, and tricyclene $(10.04 \%)$ (Table 1). Five principal constituents were identified in the oil of $A$. squamosa L.: (E)-caryophyllene (28.71\%), (Z)-caryophyllene (14.46\%), camphene (18.10\%), $\alpha$-pinene $(7.37 \%)$, and $\beta$-pinene $(8.71 \%)$ (Table 1). Accordingly, six components present in the oils of $A$. emarginata 'terra-fria' and A. squamosa L. should be highlighted: $(E)$-caryophyllene, $(Z)$ caryophyllene, $\alpha$-humulene, camphene, $\alpha$-pinene, and $\beta$-pinene. Among the six components common to the two species, three are major components in both: (E)-caryophyllene, $(Z)$-caryophyllene, and $\alpha$-pinene. 
Note that the percentages of $(E)$-caryophyllene and $(Z)$-caryophyllene were highly similar in both oils.

A previous evaluation of the composition of the essential oil of Rollinia leptopetala R. E. Fries showed that the following major components were present: cis-4-tujanol (17.37\%), $\alpha$-terpineol (8.42\%), germacrene $\mathrm{D}(7.72 \%)$, bicyclogermacrene $(22.47 \%)$, and trans-caryophyllene (6.63\%) (synonymous with (E)-caryophyllene) (COSTA et al., 2008). A comparison of the composition of the essential oil of this species with that of the essential oil of $A$. emarginata 'terra-fria' shows that limonene, $\alpha$-pinene, sabinene, trans-caryophyllene, and $\alpha$-humulene were present in both oils. A comparison of the composition of the essential oil of $R$. leptopetala studied by Costa et al. (2008) with that of the essential oil of A. squamosa L. shows that $\beta$-elemene, $\alpha$-humulene, $\alpha$-pinene, and trans-caryophyllene are common to both species. These observations show that $\alpha$-pinene, trans-caryophyllene, and $\alpha$-humulene occur in the essential oils of the three species $R$. leptopetala $\mathrm{R}$. E. Fries, A. emarginata 'terra-fria', and A squamosa. Of these constituents, trans-caryophyllene is a major component and shows anti-inflammatory activity (FERNANDES et al., 2007).

Thang et al. (2012) evaluated the essential oils of A. glabra L., A. squamosa L., A. muricata L., and $A$. reticulata L., all grown in Vietnam. The authors found 48 components in the essential oil of A. squamosa L., among which $\alpha$-pinene, $\beta$-pinene, $\alpha$-humulene, $\gamma$-himachalene, camphene, and $\beta$-elemene were also found in the essential oil of $A$. squamosa L. in the present study. It was also found (E)-caryophyllene, $(Z)$-caryophyllene, $\alpha$-humulene, $\gamma$-himachalene, $\delta$-elemene, camphene, $\alpha$-pinene, $\beta$-pinene, $\beta$-elemene, and longifolene in the essential oil of $A$. squamosa $\mathrm{L}$. These results show that the essential oil of $A$. squamosa grown in Vietnam had a greater number of components than that of the plants of this species grown in Brazil in the present study. The comparison between the results from Brazil and Vietnam highlights that the major components of the essential oil of this species may vary, due to, e.g., to climatic conditions, soil, nutrition, and water availability (MORAIS, 2009). Although the composition of the essential oil of $A$. squamosa grown under different conditions may vary, $\alpha$-pinene and $\alpha$-humulene were found in both studies cited and have also been observed in studies of other plant species (CYSNE et al., 2005; KAMATOU et al., 2008; ZEBELO et al., 2012).

Among the components identified in the essential oil of both species of Annonaceae evaluated in this study, trans-caryophyllene has also been isolated from the essential oil of Cordia verbenacea and showed anti-inflammatory activity, offering an attractive alternative for treating inflammation (FERNANDES et al., 2007). Limonene may be used as a flavor and fragrance in food preparation, to reduce the fat content of chocolate and in the biological control of insects (ROBALO et al., 2007). $\beta$-elemene has been shown to inhibit the growth of glioblastoma multiforme cells, found in a common and aggressive type of brain tumor (YOA et al., 2008). The substances $\alpha$-pinene and $\beta$-pinene have bactericidal activity (LEITE et al., 2007). Camphene is the precursor of theosemicarbazide, which has fungicidal activity (YAMAGUCHI et al., 2009). Therefore, this study identified essential oil components with known biological activity and additional components whose activity should be evaluated. 
TABLE 1- Chemical composition (\%) of the essential oils of Annona emarginata (Schltdl.) H. Rainer 'terrafria' variety and Annona squamosa L.

\begin{tabular}{|c|c|c|c|c|}
\hline Substances & $\begin{array}{c}\text { Annona emarginata (Schltdl.) H. Rainer } \\
(\mathbf{\%})\end{array}$ & $\begin{array}{c}\text { Annona squamosa } \mathrm{L} . \\
(\mathbf{\%})\end{array}$ & RI * & $\mathbf{R I}$ ** \\
\hline \multicolumn{5}{|l|}{ Monoterpene } \\
\hline Triciclene & 10.04 & - & 926 & 926 \\
\hline$\alpha$-Pinene & 13.86 & 7.37 & 933 & 939 \\
\hline Camphene & 1.33 & 18.10 & 947 & 953 \\
\hline Sabinene & 1.96 & - & 971 & 976 \\
\hline$\beta$-Pinene & 1.83 & 8.71 & 976 & 980 \\
\hline Ortho cimene & 1.93 & - & 1021 & 1022 \\
\hline Limonene & 1.07 & - & 1027 & 1031 \\
\hline \multicolumn{5}{|l|}{ Sesquiterpene } \\
\hline$\delta$-Elemene & - & 1.15 & 1337 & 1339 \\
\hline$\beta$-Elemene & - & 1.69 & 1391 & 1391 \\
\hline Longifolene & - & 5.64 & 1399 & 1402 \\
\hline (Z)-Caryophyllene & 16.86 & 14.46 & 1405 & 1404 \\
\hline (E)-Caryophyllene & 29.29 & 28.71 & 1418 & 1418 \\
\hline$\alpha$-Humulene & 3.06 & 4.41 & 1445 & 1454 \\
\hline$\gamma$-Himachalene & - & 2.96 & 1476 & 1476 \\
\hline$\gamma$-Muurolene & $7.54 \%$ & - & 1475 & 1477 \\
\hline Monoterpene & $32.02 \%$ & $34.18 \%$ & - & - \\
\hline Sesquiterpene & $56.75 \%$ & $59.02 \%$ & - & - \\
\hline TOTAL & $88.77 \%$ & 93.2 & - & - \\
\hline
\end{tabular}

(*) ri - retention index of the sample (**) ri - retention index of the literature (adams, 2007).

\section{CONCLUSIONS}

The analysis of the chemical constituents of the essential oils of the species $A$. emarginata 'terra fria' and $A$. squamosa identified monoterpenes and sesquiterpenes. Six substances were common to both species: $\alpha$-humulene, $(Z)$-caryophyllene, $(E)$ -caryophyllene, camphene, $\alpha$-pinene, and $\beta$-pinene. These two Annona species shared more than $50 \%$ of the same components of their essential oils.

\section{REFERENCES}

ADAMS, R.P. Identification of essential oil components by gas chromatography/ mass spectroscopy. Illinois: Allured Publishing Corporation, 2007. 468p.

BAKKALI, F. et al. Biological effects of essential oils - A review. Food and Chemical Toxicology, Oxford, v.46, p.446-475, 2008.

BARON, D. et al. The effect of the ionic strength of nutrient solution on gas exchange, ionic concentration and leaf biomass of Annona emarginata (Schltdl.) $\mathrm{H}$. Rainer variety 'terra-fria' seedlings. Journal of Plant Nutrition, New York, 2013. No prelo

BOYOM, F. F. et al. Potent antiplasmodial extracts from Cameroonian Annonaceae. Journal of Ethnopharmacology, Lausanne, v. 134, p. 717-724, 2011. 
CHATROU, L. W. et al. The natural history of Annonaceae. Botanical Journal of the Linnean Society, London, v. 169, p.1-4, 2012.

CHAVAN, M. J.et al., Major volatile constituents of Annona squamosa L. bark. Natural Product Research, Abingdon, v. 20, n. 8, p. 754-757, 2006.

COSTA, E.V. et al. Antimicrobial and antileishmanial activity of essential oil from the leaves of Annona foetida (Annonaceae). Quimica Nova, São Paulo, v. 32, p.78-81, 2009.

COSTA, V. C. O. et al. Composição química e modulação da resistência bacteriana a drogas do óleo essencial das folhas de Rollinia leptopetala $R$. E. Fries. Revista Brasileira de Farmacognosia. Brazilian Journal of Pharmacognosy, Curitiba, v.18, n.2, p. 245-248, 2008.

COUVREUR, T. L. P. et al. Keys to the genera of Annonaceae. Botanical Journal of the Linnean Society, London, v. 169, p.74-83, 2012.

CYSNE, J. B. Leaf essential oils of four piperspecies from the state of Ceará - northeast of Brazil. Journal of the Brazilian Chemistry Society, Campinas, v. 16, n. 6B, p. 1378-1388, 2005.

EDRIS, A. E. Pharmaceutical and therapeutic potentials of essential oils and their individual volatile constituents: a review. Phytotherapy Research, London, v.21, p. 308-323, 2007.

FERNANDES, R. S. et al. Ati-inflammatory effects of compounds alpha-humulene and (-) trans-caryophyllene isolated from the essential oil of Cordia verbenaceae. European Journal of Pharmacology, Amsterdam, v. 569, p. 228-236. 2007.

HOAGLAND, D.R.; ARNON, D.I. The water: culture method for growing plants without soil. Berkeley: California Agricultural Experiment Station, 1950. 32p.

KAMATOU, G. P. P. et al. Seasonal variation in essential oil composition, oil toxicity and the biological activity of solvent extracts of three South African Salvia species. South African Journal of Botany, Pretoria, v. 75, n. 2, p. 230-237, 2008.
KAVATI, R.; WATANABE, H.S. Anonáceas. In: DONADIO, L. C. (Org.). História da fruticultura paulista. Jaboticabal: Sociedade Brasileira de Fruticultura, 2010., 99 p.

LEBOEUF, M. et al. The phytochemistry of the Annonaceae. Phytochemistry, New York, v. 21, n. 12, p. 2783-2813, 1982.

LEITE, A. M.et al. Inhibitory effect of $\beta$-pinene, $\alpha$-pinene and eugenol on the growth of potential infectious endocarditis causing Gram-positive bacteria. Brazilian Journal of Pharmaceutical Sciences, São Paulo, v. 43, p.121-125, 2007.

LIMA, J. A.D. S. et al. Agrupamento de espécies arbóreas de uma floresta tropical por características de solo. Pesquisa Agropecuária Brasileira, Brasília, v.38, p. 109-116, 2003.

LIMA, L. A. R. S. et al. Antioxidant and cytotoxic potential of fatty acid methyl esters from the seeds of Annona cornifolia A. St.-Hil. (Annonaceae). Food Research International, Barking, v. 48, p.873-875, 2012.

LIMA, M. D. Perfil cromatográfico dos extratos brutos das sementes de Annona muricata L. e Annona squamosa L. através da cromatografia líquida de alta eficiência. 2007. 102 f. Dissertação (Mestre em Auímica e Biotecnologia) - Universidade Federal de Alagoas, Maceió, 2007.

MORAIS, L.A. S. Influência dos fatores abióticos na composição química dos óleos essenciais. Horticultura Brasileira, Brasília, v. 27, n. 2, p. S4.050-S4.063, 2009.

MUGANZA, D. M. et al. In vitro antiprotozoal and cytotoxic activity of 33 ethonopharmacologically selected medicinal plants from Democratic Republic of Congo. Journal of Ethnopharmacology, Lausanne, v.141, p. 301- 308, 2012.

OCAMPO, D. M. S.; OCAMPO, R. C. Bioactividad de la Familia Annonaceae. Revista Universidad de Caldas, Bogotá, v.26, n.1/2, p. 135-155, 2006.

POTZERNHEIM, M. C. L.et al. Análise dos óleo essenciais de três espécies de Piper coletadas na região do Distrito Federal (Cerrado) e comparação com óleo de plantas procedentes da região de Paraty-RJ (Mata Atlântica). Revista Brasileira de Farmacognosia, Curitiba, v. 16, p. 246-251, 2006. 
RAINER, H. Monographic studies in the genus Annona L. (Annonaceae): inclusion of the genus Rollinia A.St. Hil. Annalen des Naturhistorischen Museums in Wien,Serie B Botanik und Zoologie, Wien, v.08B, p.191-205, 2007.

REGNAULT-ROGER, C. et al. Essential Oils in Insect Control: Low-Risk Products in a High-Stakes World. Annual Review of Entomology, Stanford, v. 57, p. 405-424, 2012.

REIS, C. N. Annona muricata: análise química e biológica dos frutos de gravioleira. Rio de Janeiro, 2011. 150f. Dissertação (Mestre em Produção Vegetal) - Universidade Estadual do Norte Fluminense Darcy Ribeiro, Campos dos Goytacazes, 2011.

RIVOAL, A. et al. Environmental control of terpene emissions from Cistus monspeliensis L. in natural Mediterranean shrublands. Chemosphere, Oxford, v.78, p.942-949, 2010.

ROBALO, P. et al. Protocolos dos trabalho prático. Lisboa: Instituto Superior de Engenharia de Lisboa, 2007. 15-19 p.

SEFFRIN, R. C. et al. Effects of crude seed extracts of Annona atemoya and Annona squamosa L. against the cabbage looper,Trichoplusia $n i$ in the laboratory and greenhouse. Crop Protection, Guildford, v. 29, p. 20-24, 2010.

SIMÕES, C.M.O.; MARIOT, A. Farmacognosia: da planta ao medicamento. 5.ed. Porto Alegre: Ed. Universidade, 2003. 1102p.

SIQUEIRA, C.A.T. et al. Chemical constituents of the volatile oil from leaves of Annona coriacea and in vitro antiprotozoal activity. Revista Brasileira de Farmacognosia. Brazilian Journal of Pharmacognosy, Curitiba, v. 21, n. 1, p. 33-40, 2011.

SPERRY, J. S. Hydraulic constraints on plants gas Exchange. Agricultural and Forest Meteorology, Amsterdam, v. 104, n. 1, p. 13-23, 2000.

SURVESWARAN, S. et al. Generic delimitation and historical biogeography in the early-divergent 'ambavioid' lineage of Annonaceae: Cananga, Cyathocalyx and Drepananthus. Taxon, Ultrecht, v.59, n.6, p.1721-1734, 2010.
THANG, T.D et al. Study on the volatile oil contents of Annona glabra L., Annona squamosa L., Annona muricata L. and Annona reticulata L., from Vietnam. Natural Product Research, Abingdon, v.27, n.18, p.1232-1236, 2012.

TOKUNAGA, T. Cultivo de atemoia.Campinas: CATI, 2005. 80p. (Boletim Técnico, 233).

VAN DOOL, H.; KRATZ, D. J. A generalization of the relation index system including liner temperature programmed gas-liquid partition chromatography. Journal of Chromatography, Amsterdam, v. 11, p. 463-467, 1963.

WANG, H. W. et al. Comparative seasonal variation and chemical composition of essential oils from the leaves and stems of Schefflera heptaphylla using microwave-assisted and convention hydrodistillation. Industrial Crops and Products, Amsterdam, v. 36, n. 1, p.229-237, 2012.

YAMAGUCHI, M. U. et al. Effects of a thiosemicarbazide camphene derivative on Trichophyton mentagrophytes. Journal of molecules. v.14, n.10, p. 1796-1807, 2009.

YOA, Y. Q. et al. Anti-tumor effect of $\beta$-elemene in glioblastoma cells depends on $\mathrm{p} 38$ MAPK activation. Cancer letters, Amsterdam, v. 269, p.127-134, 2008.

ZEBELO, S. A. et al. Plasma membrane potential depolarization and cytosolic calcium flux are early events involved in tomato (Solanum lycopersicon) plant-to-plant communication. Plant Science, Limerick, v. 196, p. 93-100, 2012.

ZHOU, L. et al. Molecular phylogenetics of Uvaria (Annonaceae): relation-ships with Balonga, Dasoclemaand Australian species of Melodorum. Botanical Journal of the Linnean Society, London, v. 163, p. 33-43, 2010. 